\title{
DESIGNING THE LANGUAGE COMPONENT OF A SUPPORT PROGRAMME FOR TEACHERS IN MULTICULTURAL SECONDARY SCHOOLS IN SOUTH AFRICA
}

\section{Johan J Swartz}

With the transition to multicultural education in South Africa, black pupils enrolling at English medium secondary schools are compelled to study English as a first language, although they are not English mother tongue speakers. A needs investigation has revealed that these pupils struggle to cope with English, not only in the language class, but also across curricula. The needs analysis further identified the specific language and cognitive skills these students need most for academic success. Language teachers at English medium schools have not been trained to teach English as a second or foreign language, and therefore need support a.nd guidance to cope with this challenging situation. In response to this need a large-scale project, aimed at promoting the professional growth of teachers in multicultural schools, was undertaken by the Centre for Educational Development at the University of Stellenbosch. This article describes the scope of the programme, focusing on the design of the language skills component as based on the needs investigation. Part of the programme is devoted to demonstrating how selected thinking skills can be integrated with the teaching of language skills, using a communicative approach. In addition, a brief indication is given of the in-service training teachers need to undergo in order to implement these language and cognitive skills across curricula.

Met die oorgang na multi-kulturele ondenvys in Suid-Afrika, word swart leerlinge wat aan Engelsmediumskole studeer, verplig om Engels as eerste taal te neem, tenvyl hulle inderwaarheid tweede- of vreemdetaalsprekers is. 'n Behoeftebepaling het aangedui dat hierdie leerlinge emstige probleme met Engels ondervind, nie net in die taalklas nie, maar oor die kurrikulum heen (aangesien Engels die medium van onderrig in alle vakke is). Die behoeftebepaling het ook spesifieke leemtes m.b.t. taal- en kognitiewe vaardighede, wat as noodsaaklik vir akademiese sukses beskou word, uitgewys. Taalonderwysers by Engelsmediumskole is nie opgelei om Engels as ' $n$ tweede of vreemde taal aan te bied nie en het derhalwe steun en voorligting nodig om die situasie te bowe te kom. Om in hierdie behoefte te voorsien, het die Sentrum vir Ondenvysontwikkeling van die Universiteit van Stellenbosch 'n grootskaalse projek ondemeem, gemik op die professionele groei van ondenvysers in multi- kulturele skole. Hierdie artikel beskryf die omvang van die projek, met die klem op die ontwerp van die taalkomponent. 'n Deel van die program word gewy aan 'n demonstrasie van hoe geselekteerde denkvaardighede met taalonderrig gei'ntegreer kan word deur gebruikte maak van

'n kommunikatiewe taalonderrigbenadering. Voorts word aangedui hoe onderwysers indiensopleiding in die gebruik van hierdie metodes kan ontvang, sodat die taal- en kognitiewe vaardighede oor die kurrikulum heen geiinplementeer kan word.

\section{1}

INTRODUCTION

The anticipation of a new South Africa has precipitated debate on every aspect of our society. Education is one of the fields that has received considerable attention, and rightly so. Much has been published on education policy, teacher training, curriculum design and teaching methodology. However, one of the areas that has not received the attention it warrants, but which 1 s of immediate concern, is the support many teachers are likely to require when confronted by pupils from vastly different language and cultural backgrounds in the same class. 
:h the transition to non-racial education in South Africa, many schools have admitted lils from all races and cultures. This multicultural school system brings with it amnsibility on the part of teachers to provide a relevant and stimulating education gramme that will enable all pupils to develop to their full potential. However, very few chers have been adequately prepared for this situation, either at university or college; 1 , or through their own experience. These are new challen es which both pupils and chers are required to face. Addressing these challenges reqmres the skills of experts in ious fields. Undoubtedly, one of the most important of these fields is language.

\section{RATIONALE FOR THE SUPPORT PROGRAMME}

:esponse to appeals by teachers in multicultural schools, the Open Schools Association organisation established to address the needs of multicultural education) approached Centre for Educational Development at the University of Stellenbosch (CEDUS) for lstance. A needs analysis was carried out, which confirmed the existence of problems uiring urgent attention. CEDUS then appointed a team of experts from various fields to duce a multi-disciplinary programme consisting of a video tape, written materials and a cher training component, aimed at providing appropriate knowledge and skills for use in lticultural classrooms. The main objective of the programme is to empower high school chers to provide academic support for all pupils in integrated schools, especially during transition phase.

The programme was developed from July 1992 to August 1993 and focuses on the four in areas which research has shown pose problems during the transition phase to non- ial education. These four areas are:

1. Inter-personal awareness and socio-cultural skills: Both the educationally disadvantaged and the advantaged pupils need guidance in accommodating one another in the school context. Social anthropological research is needed to help pupils get to know and accommodate different cultural norms.

2. Intra-personal skills: Educationally disadvantaged pupils finding themselves in an unfamiliar milieu are likely to lack the confidence and assertiveness necessary to derive maximum benefit from their schooling. They may question their ability to cope, and their self-esteem may suffer. If these pupils are to prosper in their new environment, the use of carefully selected strategies and approaches to boost their confidence and inner locus of control is essential

3. Cognitive development skills: As some pupils in the multicultural classroom will be products of a cognitively deprived home and school milieu, it is essential that strategies be adopted to address these identified needs. The explicit teaching of thinking skills has been thoroughly researched and tested in practice, and can effectively be integrated into the multicultural curriculum.

4. Language skills: Teachers at the target schools have been trained to teach English as a first language. The pupils requiring language assistance on second or even third language level consequently present a major problem, especially as English is also the medium of instruction for all subjects. Language teaching approaches need to be adapted to address this need.

11ust be emphasized that the focus in all four components of the programme is on black 1ils. The reason for this is twofold: In the first place, black pupils are the products of a ture different from that of the majority of (white) pupils in the open schools that they md. These cultural differences need to be understood and accommodated to ensure a monious school atmosphere conducive to academic success. Secondly, black pupils are 1-mother tongue speakers of English, and this is particularly relevant in the design of the guage component. 
The inclusion of a lan uage component in the support programme for multicultural schoc is clearly a top prionty. The language barrier is a major problem facing pupils fro different cultural backgrounds who enrol at English medium schools. Deficient langual proficiency certainly poses the greatest academic problem as it is through language that pupil gains access to knowledge in all subjects.

It is significant that :pupils who have been admitted to these English medium schools a generally proficient $\mathrm{m}$ spoken English and appear to understand the spoken word fail welL They are constantly exposed to English in the school milieu and are forced to use regularly: thus their oral skills are continually upgraded in a defocused and spontaneo manner.

However, this does not mean that these pupils are able to understand expository texts (as typical textbooks) with equal ease or are able to express themselves clearly in writing. lack of these skills will not only hamper academic success, it will also affect pupils' sod adjustment to a strange environment, as well as their self-confidence and overall self-imag

This article describes the design of the language skills component, commencing with tl investigation into the actual needs of teachers and pupils alike, and outlininthe content the programme and the recommended methods of implementation. A bnef reference also made to the implications for in-service teacher training.

\section{AN INVESTIGATION INTO THE LANGUAGE NEEDS OF BLACK PUPILS IN OPEN SCHOOLS}

Before a support programme for language teachers could be designed, an investigation in the actual language needs of the identified target group of pupils was undertaken. This included a situational analysis of the multicultural language classroom in selected open schools. The investigation was threefold: reference to relevant language teachi literature; a series of questionnaires completed by both teachers and pupils representative schools, and a visit to a cross-secuon of open schools throughout the count: involving classroom observation and interviews with principals, language teachers al selected pupils.

The South African situation is virtually unique in that black pupils enrolling at socalled 'white' English medium schools form an anomalous group, coming as they do from vario cultural and language backgrounds, and constituting, at this stage, a small minority in the language classrooms. The available literature does not address this problem specifical but does confirm, in a broader sense, the problems stemming from pupils' inadeqm proficiency in the medium of instruction (Appel and Muysken, 1987). The ap:pare connection between language proficiency and the development of conceptual skills 1s al highlighted, with the implication that pupils with insufficient language skills may handicapped in developing necessary study skills such as reasoning, formulating a negotiating concepts (Macdonald, 1990). Thus improving pupils' language skills may serve as a means to a broader, cognitive end.

The questionnaires sent out to a sample of twenty-one randomly selected secondary schools, affiliated to the Open Schools Association, requested, inter al1a, the following data

- the number of pupils in each language class

- the number of black pupils in each language class the average symbol for

- English of the whole class the average symbol for English of the black pupils 
- the teacher's assessment on a five-point scale of his/her black pupils' language needs with regard to listening, speaking, reading, writing, and vocabulary

- the teacher's view on the feasibility of accommodating non-mother tongue pupils in the same language class as mother tongue speakers, and an explanation of this viewpoint

- an indication of what the language teacher does to improve the language proficiency of black pupils in the class

- the teacher's assessment of the relative importance of the various components of the English First Language syllabus in the teaching of black pupils

— a description of the method(s) used by each teacher to teach English L1

- the language teacher's opinion regarding the particular language skills his/her black pupils need to cope with other subjects in the curriculum taught through the medium of English

- the language teacher's assessment of his/her ability to teach black pupils these skills, given the status quo, and of his/her need for training and support to address these needs.

All the language teachers at each selected school were requested to complete the questionnaire, and the following findings apply to the situation in open schools.

- Black pupils in standards six, seven and eight are struggling to cope with English. The average symbol for English First Language in the standard six classes is a D, whereas that for black pupils in the same classes is an FF - a failing mark. The situation is slightly better for the average black pupil in standards seven and eight - an E symbol as opposed to a D for the class as a whole. Black pupils make up between 12 and 17 per cent of the total number of pupils in the standard six to eight classes.

- Teachers asked to rate black pupils' language needs in order of importance, consistently agreed on the following:

vocabulary
reading skills
writing skills
speaking skills.

Listening skills were the only ones regarded by a significant percentage of teachers as relatively unimportant.

$84,8 \%$ of teachers consulted believe that non-mother tongue (black) pupils could and should be accommodated in the same classroom as mother tongue speakers. In ex $\{>$ lanations given, teachers nevertheless acknowledged existing problems in this regard, citmg the large difference in English proficiency levels between these two groups as paramount. This, it was reported, is to the disadvantage of both groups, thus underlining the urgent need for upgradmg black pupils' language skills. The majority felt that what is needed is an improvement in pupils' vocabulary and understanding of English texts; others suggested that adjustments need to be made to the English syllabus, that greater emphasis be placed on English across the curriculum, and that special language skills classes be arranged for black pupils. 
Regarding how to go about effecting the necessary improvements in black pupils' language skills, teachers were vague and uncertain. The commonest methods currently practised are reported to be the repeated use of explanation until some measure of comprehension is achieved, and the settmg of additional reading comprehension tests (i.e. not teaching, but testing). Other teachers conduct extra English classes and encourage these pupils to make English friends and watch more English television.

Teachers asked to rate the relative importance of the various components of the English First Language syllabus regard communication skills as paramount, followed by oral work and writing skills. The study of literature and formal languae instruction is seen as less significant in addressing the Identified needs. In describing their basic approach to teaching English First Language, the majority of teachers rel?orted using a communicative approach involving "an oral exchange of Ideas". There was little or no consensus on other methods used.

When asked which skills they believed black pupils needed most to cope with all school subjects, teachers once again rated vocabulary and reading comprehension skills highest.

Finally, more than half the respondents felt strongly that they needed to be trained in ways to assist black pupils to cope with English. This includes the need for relevant materials.

The findings of the questionnaires were largely confirmed by the observation and interviews at a number of representative schools across the country. (The schools visited are located in the Western Province, Eastern Province, Border, Transkei, and Transvaal.) A number of English lessons to mixed groups of pupils were observed in each school in order to monitor black pupils' responses to specific language components. Thereafter, interviews with both teachers and black pupils were conducted to identify and assess the extent of the problems experienced. The interviews with pupils proved most enlightening, enabling pupils to reveal their language problems at first hand. During the interviews, pupils were required to read passages selected from textbooks for other subjects, at their level, to demonstrate their ability to comprehend written text. Passages from a geography textbook, for example, included one on climatoloi: $\mathrm{D}^{\prime}$ and on the structure of the earth. Passages from a science textbook were on electricity and on the density of substances. Typical comprehension passages from an English textbook were also used. A number of questions were put to after the passages had been read, and they were allowed to discuss these in groups.

The pupils claimed to have understood the passages they had read, and could identify no difficult words when asked to do so. However, they fared badly in their attempts to answer any questions requiring insight rather than mere retrievaL They were also unable to work out the meanings of unfamiliar words from their context (despite having professed previously to understand all the words in the passage).

In summary, the questionnaires and visits to schools reveal that black pupils at English medium schools appear to be generally proficient in spoken English, and do not appear tc have major problems with listening skills. This is confirmed by much of the language teaching literature which advocates constant exposure to and use of English in a natural and defocused manner (as in the English medium school milieu) to promote language acquisition. However, as anticipated, the grammatical accuracy of these pupils is generall) below standard.

The most urgent needs are the upgrading of reading comprehension skills, writing skills and general study skills, as well as extension of vocabulary and the correct use of idiomatic English. The language support programme attempts to address these needs as effectively a! possible. 


\section{DESIGNING THE SUPPORT PROGRAMME}

\subsection{OPTIONS}

Once the major language problems that need to be addressed had been identified, several options regarding the design of the language support programme presented themselves. The options related to the specific content of the programme, the methods of implementation, as well as the specific target group for whom the programme is intended. The following factors influenced the available options:

- While it is clear that black pupils require assistance with reading comprehension and writing skills, as well as related study skills, it is equally true that many white pupils have similar problems, though probably on a smaller scale. The option was thus to design a programme which could be of benefit to all pupils, or one for the exclusive use of black pupils.

- Most teachers agreed that black pupils should be accommodated in the same classes as mother tongue speakers, with separate lessons used only to supplement the mainstream syllabus. This raises the Issue of how to integrate the support material with existing syllabus content, given the constraints of time, size of classes and discrepancies in language proficiency levels within a class.

- The programme has a limited scope. At best it can demonstrate only a very few methods of teaching and ways of generating materials that could be used in a prescribed number of lessons (or module), and then developed further by the teachers themselves. This meant that the specific skills and materials to be demonstrated had to be carefully selected.

- The programme allows for the production of a professional video. Thus a decision had to be made: which skills to demonstrate through the visual medium, and which through the printed word. It was noted that the video medium was ideally suited to a demonstration of second language teaching methods to teachers who had been trained to teach the mother tongue.

- The materials chosen could focus exclusively on the requirements of the Ll syllabus, or could address the need for language across the curriculum (as indicated by the needs investigation). The latter option would involve the integration of relevant cognitive and study skills with materials drawn from other curriculum subjects.

After all options had been considered, the programme consisting of a video component and a written workbook was designed. Each of these components addresses a distinct language need, though both are related to the use of English across the curriculum.

\subsection{THE VIDEO COMPONENT}

It was decided to use the video component for two main purposes: to demonstrate how the teaching of specific thinking skills can be integrated w1th language teaching, on the one hand, and, on the other hand, to demonstrate a communicative language teaching (CLT) method.

A close connection exists between the development of language and cognitive skills. As thinking is virtually impossible without language, it follows that deficient language skills will impair a child's understanding of specific subject matter. 
The study of subjects such as Maths and Science through the medium of English may require the understanding of concepts which may not even exist in the pupils' mother tongue. In order to grasp these terms, the non-English speaker may require more than just improved language proficiency - he may need to acquire specific cognitive skills, or to adopt a different mode of thinking.

In recent years it has been acknowledged that thinking can be explicitly taught and learned. Specific thinking skills or tools can thus be introduced into a school curriculum. The question arises: which is the most appropriate context or subject in which to do this?

As language and thinking are virtually inseparable, their combination occurs naturally in the classroom. It should thus be possible to promote the one by teaching the other - or so to fuse the two that they are mutually enriching. Furthermore, the teaching of thinking strategies shares a common ground with second language teaching as it, too, 1s best taught by pair and group interaction (Puhl, 1991).

The video programme portrays a problem situation with which J?Upils in open schools can identify (it was suggested during one of the interviews w1th pupils), viz. whether participation in sport should be made compulsory for all pupils. Visual material shows black and white pupils arguing this issue as the school sports day approaches. The resultant one-sided views raised, broaden an already existing rift between the two groups of pupils. The language teacher then demonstrates how this problem can effectively be addressed by using a series of thinking strategies. Each of these strategies Is explained and demonstrated, then pupils are given an opportunity to practise each one in a different context in the form of a group activity. Each activity requires the members of the group to communicate with one another as they apply the thinking skill to the problem at hand. This requires spontaneous speaking in a natural, defocused way, with the emphasis on getting a message across and solving a challenging problem, rather than on correct language usage.

Knowing the problem situation and the likely discussion that it will elicit, the teacher can anticipate typical language structures puJ?ils will be required to use, and can thus precede the group activity with relevant language mput, focusing on one or two particular structures. The example demonstrated in the video programme involves the use of IF in conditional clauses when speculating on the implications of pupils' participation in compulsory sport activities. The teacher can then momtor the use of this structure in the oral discussions.

When several thinking skills have been demonstrated to and practised by the pupils, they are requested to try to reach consensus in their groups regarding a solution to the problem of whether participation in sport should be made compulsory or not. This could also be the basis of a written activity $m$ which specific language structures and functions (such as agreeing, disagreeing, settmg conditions, explaining, etc.) feature. Thus this communicative activity feat res the lan age.skills of listening, speaki;t. and writing, aJ?.d can also be extended to mclude readmg skills (though these are specifically catered for $m$ the teacher's workbook). The possibilities for usinthinking skills in communicative activities of this nature are endless, and the teacher is encouraged to design similar activities to those demonstrated in the video.

\subsection{THE TEACHER'S WORKBOOK}

As noted previously, black pupils enrolling at English medium schools are required to study all their subjects through the medium of English, which is not their mother tongue.

It cannot be assumed that, because a pupil is able to understand the teacher in class, and can read English with relative ease, he will also understand expository text with equal ease or be able to express himself clearly in writing. To accomplish these demanding tasks in a language that is not his mother tongue requires the mastery of specific and often complex language skills, as well as related academic skills - what has been termed CALP: cogmtive 
1cademic language proficiency. These skills especially come into play when a pupil has to nake sense of written texts, virtually an everyday task. As the needs assessment revealed hat pupils struggle to understand subject texts (which implies a restricted vocabulary, the nabiiity to derive meaning from context by using contextual clues, a misunderstanding of liscourse markers, etc.), it is on this skill that the teacher's workbook focuses.

Teachers in open schools who were consulted in the needs investigation, believe that these 1eeds are not confined to black pupils, but apply to a large percentage of English mothertongue speakers as well. Thus it seems appropriate to incorporate the developed materials nto the English mainstream lessons.

The teacher's workbook demonstrates how a subject-specific text can be used to teach and practise specific language skills that are closely related to study skills. First a number of macro-language functions, relevant to the understandinand study of subject texts, was identified. These include skills such as defining, simplifymg, logical sequencin, extracting main ideas from a text for the purpose of summarizing, generalizing, classifying, and the ike. From this it is apparent that some of the material in the teacher's workbook should beof interest and use to non-language teachers as well. This material could be used in other ubject lessons in an attempt to make specific subject matter more accessible to pupils.

The text on which the lessons in the workbook are based is taken from a standard six geography textbook. In fact, any subject text could have been chosen. The passage deals l'ith the factors that influence weather and climate. The lessons based on it are outlined, tep by step, from the pupils' point of view. This is done to make the approach and the natenal as user-friendly as possible.

The lessons outlined in the workbook may take as many as eight periods to complete. The aims of these lessons are summarised as follows:

— To demonstrate an effective technique for reading a formal text

- To understand the structure of a formal text

— To practise skills like skimming, scanning, note-taking, identifying main points, etc. To use contextual clues to work out the meanings of unfamiliar words

- To practise macro-functions like defining, simplifying, explaining, generalizing and classifying, within a given context

— To understand the function of particular grammatical features of a text

- To apply knowledge gained from one source to a different context

— To write clear, coherent summaries of longer material

The following activities form the basis of the lessons in the workbook:

Pre-reading

This involves skimming the passage, paying particular attention to headings, sub- headings, words in bold and italics, diagrams, graphs, etc. Pupils are then required to tell a partner the gist of what they have read.

\section{Scanning for infomation}

Questions are set and pupils are asked to read the passage a second time to find specific information as quickly as possible. 


\section{- Finding the main points in a paragraph}

Pupils are required to match jumbled topic sentences with paragraph numbers. Working in pairs, they must then find the topic sentence of each of the last fom paragraphs.

\section{- Understanding the structure of the text}

Pupils are shown how information that belongs together is included in the same paragraph, and how devices for linking paragraphs are used. They are guided tc assess the way in which the twelve paragraphs of the text are logically connected, anc to discover examples of weak cohesion. This activity is also carried out in pairs.

\section{— Working out the meaning of unfamiliar words}

Pupils are shown how to identify and use contextual clues to work out the meaning! of unfamiliar words in a passage. Several examples are demonstrated, then pupil are requested to practise this method in pairs.

\section{- Understanding the grammatical features of a text}

Pupils are introduced to the functions of logical connectors and reference devices They must then find further examples of these in the passage and work out thei1 functions, in pairs.

A different grammatical feature that is emphasized in these lessons is tht appropriate use of the passive voice. Examples of its use are pointed out; pupils an invited to compare these with the use of the active voice, and both the formation anc function of the passive are demonstrated in a realistic context. Pupils then look fo1 further examples of the passive and indicate why they consider its use appropriate 01 inappropriate in context.

\section{- Using macro-language functions}

Language functions are actions that are performed when using language. A fe" elementary functions are explained to pupils (e.g. apologizing), and then they an given specific instructions to carry out in groups. These instructions, in the form o questions based on the text, require pupils to use macrofunctions such a! simplifying, explaining, defining, classifying and generalizing.

\section{— Writing summaries}

Using skills previously learned, pupils are asked to identify the main points in th various sub-sections of the passage and to link them to form a coherent summary which could be used for revision purposes. This is done in groups.

\section{- Applying knowledge}

Pupils work in groups. They are asked to select a part of the country which the] would like to visit on holiday. Their choice has to be based on the climatic conditions of that area, and this requires the application of knowledge gained frorr the text on climatology. The linkmof weather conditions with specific holidaJ activities makes this a realistic and enjoyable group activity. Feedback is then giver to the whole class. 
It should be apparent from the above outline, that many of the activities in the workbook, like those demonstrated on the video, require roup and pair work involving pupils in genuine communication. Thus defocused learmng occurs while specific language/study skills are practised.

Given the limited scope of the programme, only a small number of lan uage and study skills can be covered $m$ the workbook. It is thus the teacher's responsibility to expand on this model and to generate his/her own lessons by using a variety of texts from various subjects. In this way, the use of language across curricula can be promoted in a r realistic context.

The complete support programme has been designed for independent use by schools as part of a professional growth programme for teachers. The principal and semor staff at a school can run the programme over a period of time that suits their needs best. Specific guidelines, as well as additional materials, suggested activities and a comprehensive set of transparencies are provided to facilitate training.

During the language skills training sessions, teachers work in groups. Specific tasks are set which have to be carried out in the form of guided discussions. These tasks include:

— discussing and prioritizing the language needs of non-mother tongue speakers

— considering the extent to which language proficiency affects pupils' achievements

in

— all curriculum subjects

— suggesting ways of accommodating language needs across curricula

— critically assessing the communicative approach as a means of addressing identified language needs

- considering the feasibility, as well as the advantages and disadvantages of fusing the teaching of thinking with language teaching

— identifying the language and study skills pupils need most for academic

success listing the skills pupils need in order to read and understand

expository texts discussing alternative ways of teaching the identified skills

- selecting passages/chapters from various textbooks which are considered inaccessible or less accessible to non-mother tongue pupils

- evaluating the teacher's workbook in terms of feasibility, appropriacy and methodology.

These group tasks are performed only after teachers have received specific input on the aspects to be discussed. For example, they first watch the relevant section of the video programme, or read sections of the workbook, or read an article on communicative language teaching or the teaching of thinking skills, before embarking on discussions. The group discussions should culminate in the formation of specific action plans for the most effective implementation of the language programme. This type of traininacknowledges the unique character and situation of every school, its staff and pupils, and Jt thus does not enforce the use of one particular approach to using the programme. 
In the training session, teachers are made aware of their responsibilities towards all pupils. Not only methods, but also attitudes, particularly towards pupils from different cultures, are discussed. In particular, teachers are made to realise that they should build on the models provided in the programme, and develop their own materials to cater for the specific needs of their pupils.

\section{CONCLUSION}

The language programme has been designed to be integrated with the mainstream English syllabus, and particularly to address the needs of English across curricula. Given the ltmited scope of the programme, it is possible to demonstrate suggested teaching methods in the context of only a few selected language and cognitive skills. The materials supplied should be seen as a descriptive rather than a prescriptive model, which teachers can adapt and extend according to their particular needs.

This programme does not claim to be a panacea for the language problems inherenin multicultural education. Other options, such as providing additional language input for disadvantaged pupils, may need to be considered to supplement mainstream input.

A great deal of research is still required in the field of multicultural education in South Africa. While this programme is merely a first step in that direction, it is hoped that it will enable teachers to understand and respond more effectively to the language needs of culturally diverse pupils, and to adapt their teaching accordingly.

The entire programme, including video, instructor's manual and workbooks, entitled: Open

Schools: A professional growth programme for teachers, is available from Juta, Cape Town. 


\section{BIBLIOGRAPHY}

APPEL, R and MUYSKEN, P. 1987. Language contact and bilingualism. London: Edward Arnold.

ARORA, RK and DUNCAN, CG. (eds) 1986. Multicultural education: Towards good practice. London: Routledge \& Paul.

BERWICK, R. 1989. Needs assessment in language programming: from theory to practice. In Johnson, R.K. (ed) 1989. The second language curriculum. Cambridge: Cambridge University Press.

BOYLE, JP. 1987. Intelligence, reasoning, and language proficiency. The modem language journal, 71(3): 277-288.

BREEN, MP. 1985. The social context for language learning - a neglected situation? Studies in second language acquisition, 7:135-158.

DE BONO, E. 1986. CoRT Thinking. New York: Pergamon Press.

FRADD, SH and WEISMANTEL, MJ. 1989. Meeting the needs of culturally and linguistically different students. Boston: College-Hill.

LITTLEWOOD, W. 1981. Communicative language teaching. Cambridge: Cambridge University Press.

MACDONALD, CA. 1990. Ballpoint pens and braded hair: an analysis of reasoning skills and the curriculum. Pretoria: HSRC.

PUHL, CA. 1991. Does the teaching of thinking promote language acquisition? Per

Linguam, 7(2): 27-36.

PUHL, CA and SWARTZ, JJ. 1989. Designing a second language bridging course for university students. Per Linguam, 5(1): 17-32.

SACCO, SJ. 1987. Crap detecting: an approach to developing critical reading and thinking skills in the foreign language curriculum. Foreign language annals, 20(1): 57-66.

STARFIELD, S. 1990. Contextualisinlanguage and study skills. South African journal for higher education. Special edition: 142-148.

SWARTZ, JJ and CILLIERS, CD. 1992. The integration of language and thinking skills in a bridging course for pre-university students at the Military Academy. Per Linguam, 8(1): 52-61.

VAN ROOYEN, H. 1990. The disparity between English as a subject and English as the medium of learning. Pretoria: HSRC. 